\title{
ASSOCIATION BETWEEN MANDIBULAR CANAL COURSE AND INTERFORAMINAL AREA IN PANORAMIC RADIOGRAPHS FOR IMPLANT PLACEMENT
}

\begin{abstract}
Objective: The aim of this study was to evaluate the relationship of mandibular canal course with mental foramen localization in panoramic radiographs on edentulous patients' for implant placement evaluation.
\end{abstract}

Material and Methods: This retrospective study was carried out on the panoramic radiographs of 788 edentulous patients. Horizontal measurements L (left mental foramen to the left mandibular ramus), $\mathrm{R}$ (right mental foramens to the right mandibular ramus), $\mathrm{M}$ (between the mental foramens) and vertical measurements D1 (mental foramen's inferior border to the mandibular basis), D2 (mental foramen's superior border to the alveolar crest) were digitally evaluated. Mandibular canals were classified into two types as linear and elliptic. Analysis of demographic data and correlations between canal course and linear measurements were carried out. Kolmogorov-Smirnov and Shapiro Wilks tests, Kruskal Wallis test, and Chi-squared test were used to compare the qualitative data $(\mathrm{p}<0.05)$.

Results: There was a statistically significant difference between the D1/D2 mean values and the canal course according to the age groups. The rate of the elliptic canal course in the men (41.6\%) was significantly higher than that in the women $(26.6 \%)$. There was no statistically significant difference between the mean D1/D2, $(\mathrm{R}+\mathrm{L}) / \mathrm{M}$ and $\mathrm{L} / \mathrm{M}$ values according to the canal course.

Conclusions: Both elliptical and linear canal courses do not affect the interforaminal distances, resulting ineffective in the anteroposterior spread of implants in cases of interforaminal implant placement.

Key Words: Mandibular canal, canal course, interforaminal area, canal anatomy, implant.
*Muammer Çağrı Burdurlu ${ }^{1}$

Volkan Dagasan ${ }^{1}$

Fatih Cabbar ${ }^{1}$

ORCID IDs of the authors:

M.C..B. 0000-0003-3370-7259

V.D. $\quad 0000-0001-5662-0186$

F.C. $\quad 0000-0002-9278-5668$

${ }^{1}$ Department of Oral \& Maxillofacial Surgery, Yeditepe University Faculty of Dentistry İstanbul, Türkiye.

Received $\quad: 12.08 .2020$

How to Cite: Burdurlu MÇ, Dagasan V, Cabbar F. Association Between Mandibular Canal Course and Interforaminal Area in Panoramic Radiographs for Implant Placement. 


\section{INTRODUCTION}

Edentulous mandibulas with advanced alveolar bone atrophy present cases of complex augmentation procedures especially in the posterior regions for implant-supported prosthetic rehabilitation such as grafting or nerve lateralization/transposition. ${ }^{1}$ A solution for these cases is to have implant support between the mental foramens. ${ }^{1,2}$ For the compromised biomechanical position, the anteroposterior spread of implants becomes a clinical success parameter. ${ }^{2}$

The mental foramen and mandibular canal are strategically important landmarks during implant surgery procedures. Therefore, prior to the any surgical procedures in the vicinity of the mandibular canal, it is important to conduct a thorough evaluation, involving a meticulous radiographic examination. ${ }^{3}$ Although panoramic radiography is not completely adequate to identify the mental foramen compared to computerized tomography, it is the most frequently used diagnostic imaging in routine clinical practice. ${ }^{4}$

There has been no study evaluating the emergence location of the mental foramen in comparison to the mandibular canal course in the literature. The aim of this study was to evaluate the relationship of mandibular canal course with mental foramen localization in vertical and horizontal planes on edentulous patients' panoramic radiographs for implant placement.

\section{MATERIALS AND METHODS}

This study was approved by Yeditepe University Ethical Committee, Istanbul, Turkey in accordance with the principles of the Declaration of Helsinki (Research no. 1752-1110). The study was carried out on the panoramic radiographs of 788 edentulous patients who attended Yeditepe University Faculty of Dentistry in Istanbul, Turkey. The inclusion criteria were: patients above 30 years old of both sexes, presence of edentulous mandibula, high quality imaged radiographs in which reference points are clearly visible for measurement of distances. The exclusion criteria were: trauma, pathology, surgery or congenital deformity history which might affect radiograph interpretation, anterior loop detected mental foramens and indistinct mandibular canal borders.
Panoramic radiographs taken with an Orthopantomograph model X-550 (J. MoritaMfg Coro., Kyoto, Japan) were included. Horizontal and vertical measurements were made in each patient's digital panoramic radiograph with the Sectra PACS IDS7 (Sectra AB, Sweden) software.

\section{Linear measurements}

The following measurements were recorded in millimeters $(\mathrm{mm})$ using specific reference points on the mandibula by the same operatorRe (Figure $1)$.

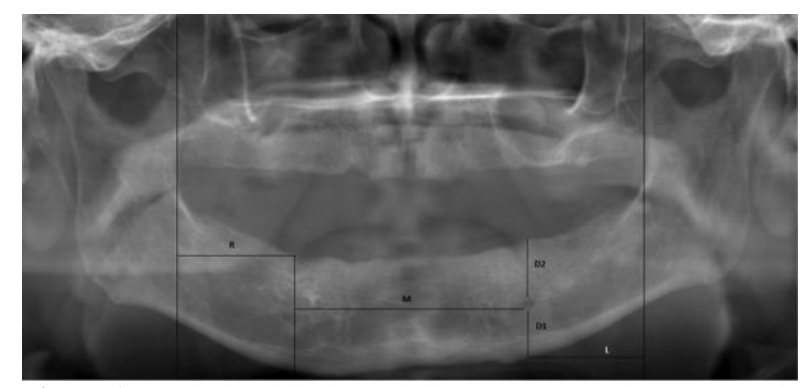

Figure 1. Vertical and horizontal distances measured on panoramic radiographs.

D1 - Vertical distance from the mental foramen's inferior border to the mandibular basis.

D2 - Vertical distance from the mental foramen's superior border to the alveolar crest.

L - Horizontal distance from the left mental foramen's posterior border to the vertical line that passes through the anterior border of the mandibular ramus in the left mandibula.

$\mathrm{R}$ - Horizontal distance from the right mental foramen's posterior border to the vertical line that passes through the anterior border of the mandibular ramus in right mandibula.

M - Horizontal distance between the anterior borders of the mental foramens.

\section{Mandibular canal course}

The mandibular canals seen on the panoramic radiographs were classified into two types: linear and elliptic. ${ }^{5}$ Visual evaluation of the canal anterior to the vertical line that passes through the anterior border of the mandibular ramus was made by 2 clinicians (Fig. 2). 


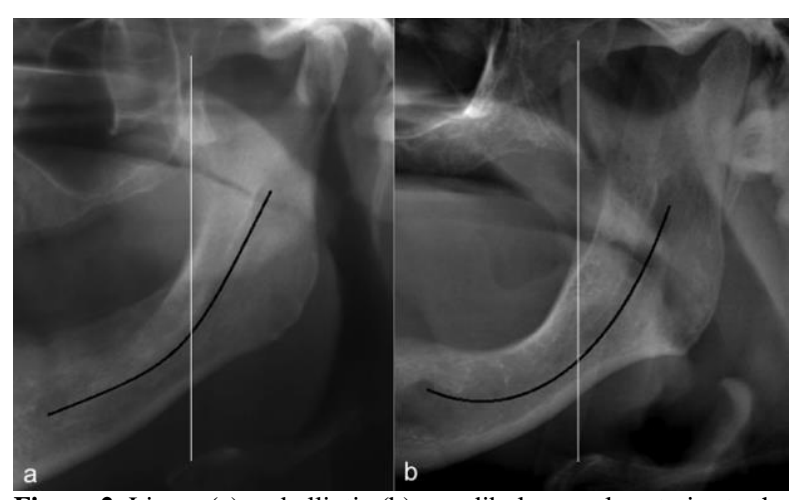

Figure 2. Linear (a) and elliptic (b) mandibular canals anterior to the vertical line that passes through the anterior border of the mandibular ramus.

Analysis of the demographic data and correlations between canal course, linear measurements, D1/D2, L/M, $(\mathrm{R}+\mathrm{L}) / \mathrm{M}$ were carried out.

\section{Statistical analysis}

The data were analyzed by descriptive statistical methods (mean \pm standard deviation). Statistical analysis was carried out using IBM SPSS Statistics 22 (SPSS IBM, Turkey). The suitability of the parameters to normal distribution was evaluated by Kolmogorov-Smirnov and Shapiro Wilks tests, and it was determined that the parameters did not show a normal distribution. Kruskal Wallis test was used for comparison of the quantitative data, and Mann Whitney $\mathrm{U}$ test was used for determination of the group causing the difference. Mann Whitney U test was used to compare the parameters between two groups. Chi-squared test was used to compare the qualitative data. The significance threshold was set at $P<0.05$.

\section{RESULTS}

The study was conducted on a total of 788 patients, of which $399(50.6 \%)$ were female, and 389 $(49.4 \%)$ were male. The mean age of the patients was $61.82 \pm 11.40$ years (Table 1 ).

Table 1. Demographic data of the participants

\begin{tabular}{llll}
\hline & & $\mathbf{n}$ & \% \\
\hline Age & $30-40$ & 18 & 2.3 \\
& $41-50$ & 111 & 14.1 \\
& $51-60$ & 247 & 31.3 \\
& $61-70$ & 224 & 28.4 \\
& $71-80$ & 141 & 17.9 \\
Sex & $81 \leq$ & 47 & 6 \\
& Female & 399 & 50.6 \\
Canal Course & Male & 389 & 49.4 \\
& Elliptic & 268 & 34 \\
\hline
\end{tabular}

n: number

The distribution of the descriptive data for the measurements is shown in Table 2.

Table 2. Evaluation of the measurements

\begin{tabular}{lllll}
\hline & Minimum & Maximum & Mean \pm SD & Median \\
\hline D1 $(\mathrm{mm})$ & 4.1 & 30.3 & $11.9 \pm 2.2$ & 11.7 \\
D2 $(\mathrm{mm})$ & 0.4 & 37 & $10.8 \pm 4.4$ & 10.8 \\
R $(\mathrm{mm})$ & 20.3 & 70.2 & $33.8 \pm 5.7$ & 33.3 \\
$\mathrm{~L}(\mathrm{~mm})$ & 20.1 & 64.3 & $34.6 \pm 5.6$ & 34.1 \\
M (mm) & 35.4 & 125.8 & $58.3 \pm 9.5$ & 57.6 \\
D1/D2 & 0.4 & 18.75 & $1.4 \pm 1.2$ & 1.1 \\
$(\mathrm{R}+\mathrm{L}) / \mathrm{M}$ & 0.65 & 2.69 & $1.2 \pm 0.3$ & 1.2 \\
L/M & 0.31 & 1.73 & $0.6 \pm 0.1$ & 0.6 \\
\hline
\end{tabular}

SD: standart deviation.

Distances in mm; L: left mental foramen to the left mandibular ramus, R: right mental foramen to the right mandibular ramus, M: between the mental foramens, D1: mental foramen's inferior border to the mandibular basis, D2: mental foramen's superior border to the alveolar crest.

There was a statistically significant difference in the canal course according to the age groups $(P$ :
$0.003 ; P<0.05$ ) (Table 3 ). In the $71-80$ years $(22.7 \%)$ and 81 and older (\%19.1) age groups, the 
rate of elliptic course was significantly lower than those in the 30-40 years (50\%), 41-50 years (39.6\%), 51-60 years $(37.2 \%)$ and 61-70 years $(36.6 \%)$ groups $(P 1: 0.02 ; P 2: 0.004 ; P 3: 0.003$; $P 4: 0.005 ; P<0.05),(P 1: 0.027 ; P 2: 0.013 ; P 3$ : $0.017 ; \quad P 4: 0.026 ; \quad P<0.05)$. There was no statistically significant difference between other age groups in terms of canal course $(P>0.05)$. In addition, the rate of elliptic canal course in the men (41.6\%) was significantly higher than that in the women $(26.6 \%)(P<0.001)$ (Table 3$)$.

Table 3. Canal course evaluation in relation to age and sex

\begin{tabular}{|c|c|c|c|c|}
\hline & \multicolumn{4}{|c|}{ Canal Course } \\
\hline & & Elliptic & Linear & $P$ \\
\hline \multirow{6}{*}{ Age } & & n $(\%)$ & n $(\%)$ & \multirow{6}{*}{$0.003 *$} \\
\hline & $30-40$ & $9(50 \%)$ & $9(50 \%)$ & \\
\hline & $41-50$ & $44(39.6 \%)$ & $67(60.4 \%)$ & \\
\hline & $51-60$ & $92(37.2 \%)$ & $155(62.8 \%)$ & \\
\hline & $61-70$ & $82(36.6 \%)$ & $142(63.4 \%)$ & \\
\hline & $71-80$ & $32(22.7 \%)$ & $109(77.3 \%)$ & \\
\hline \multirow{3}{*}{ Sex } & $81 \leq$ & $9(19.1 \%)$ & $38(80.9 \%)$ & \multirow{3}{*}{$0,000 *$} \\
\hline & Female & $106(26.6 \%)$ & $293(73.4 \%)$ & \\
\hline & Male & $162(41.6 \%)$ & $227(58.4 \%)$ & \\
\hline
\end{tabular}

Statistically significant difference was found in the D1/D2 mean values according to the age groups $(P<0.001)$ (Table 4). The D1 / D2 mean value of the 71-80 age group was significantly higher than the 30-40 years, 41-50 years and 51-60 years groups ( $P 1$ : $0.025 ; P 2<0.001 ; P 3: 0.001 ; P<0.05)$. The D1/D2 mean value of the 61-70 age group was significantly higher than the 30-40 years, 41-50 years and 51-60 years groups $(P 1: 0.044 ; P 2$ : $0.001 ; P 3: 0.043 ; P<0.05)$. The mean D1/D2 value of the 81 and older age group was significantly higher than the 30-40 years, 41-50 years and 51-60 years groups ( $P 1$ : $0.034 ; P 2$ : $0.001 ; P 3$ : 0.048 ; $P<0.05)$. There was no statistically significant difference between the other age groups in terms of D1/D2 $(P>0.05)$. Furthermore, no statistically significant difference was found in the mean $(\mathrm{R}+\mathrm{L}) / \mathrm{M}$ and $\mathrm{L} / \mathrm{M}$ values according to the age groups ( $P$ : $0.551 ; P>0.05),(P: 0.381 ; P>0.05)$ (Table 4).

Table 4. D1/D2, $(\mathrm{R}+\mathrm{L}) / \mathrm{M}$ and $\mathrm{L} / \mathrm{M}$ evaluation in relation to age groups

\begin{tabular}{|c|c|c|c|}
\hline Age & $\begin{array}{c}\text { D1/D2 } \\
\text { Mean } \pm \text { SD (median) }\end{array}$ & $\begin{array}{c}(\mathbf{R}+\mathbf{L}) / \mathrm{M} \\
\text { Mean } \pm \text { SD }(\text { median })\end{array}$ & $\begin{array}{c}\text { L/M } \\
\text { Mean } \pm \text { SD (median) }\end{array}$ \\
\hline $30-40$ & $1.11 \pm 0.49(0.96)$ & $1.17 \pm 0.23(1.12)$ & $0.59 \pm 0.11(0.56)$ \\
\hline $41-50$ & $1.28 \pm 1.77(0.97)$ & $1.18 \pm 0.23(1.17)$ & $0.59 \pm 0.11(0.58)$ \\
\hline $51-60$ & $1.30 \pm 0.83(1.03)$ & $1.21 \pm 0.26(1.18)$ & $0.61 \pm 0.13(0.59)$ \\
\hline $61-70$ & $1.52 \pm 1.28(1.09)$ & $1.2 \pm 0.26(1.16)$ & $0.61 \pm 0.14(0.59)$ \\
\hline $71-80$ & $1.65 \pm 1.26(1.28)$ & $1.19 \pm 0.24(1.16)$ & $0.60 \pm 0.13(0.58)$ \\
\hline $81 \leq$ & $1.35 \pm 0.59(1.15)$ & $1.25 \pm 0.23(1.22)$ & $0.63 \pm 0.12(0.61)$ \\
\hline $\mathrm{p}$ & $0.000^{*}$ & 0.551 & 0.381 \\
\hline \multicolumn{4}{|c|}{$\begin{array}{l}\text { Kruskal Wallis Test } \\
\text { SD: standart deviation } \\
\text { Distances in mm; L: left mental foramen to the left mandibular ramus, R: right mental foramen to the right mandibular ramus, M: between the mental } \\
\text { foramens, D1: mental foramen's inferior border to the mandibular basis, D2: mental foramen's superior border to the alveolar crest. }\end{array}$} \\
\hline $\begin{array}{l}\text { The } \mathrm{n} \\
\text { signific } \\
P<0.05\end{array}$ & $\begin{array}{l}\text { value of the won } \\
\text { than that of the men }( \\
\text { There was no sta }\end{array}$ & \multicolumn{2}{|c|}{$\begin{array}{l}\text { no statistically significant difference in the mean } \\
\mathrm{D} 1 / \mathrm{D} 2,(\mathrm{R}+\mathrm{L}) / \mathrm{M} \text { and } \mathrm{L} / \mathrm{M} \text { values according to the } \\
\text { canal course }(P>0.05) \text { (Table } 5) \text {. }\end{array}$} \\
\hline
\end{tabular}
significant difference in the mean $(\mathrm{R}+\mathrm{L}) / \mathrm{M}$ and $\mathrm{L} / \mathrm{M}$ values according to sex $(P>0.05)$. There was 
Table 5. D1/D2, $(\mathrm{R}+\mathrm{L}) / \mathrm{M}$ and $\mathrm{L} / \mathrm{M}$ evaluation in relation to sex and canal course

\begin{tabular}{lllc}
\hline & $\begin{array}{l}\text { D1/D2 } \\
\text { Mean } \pm \text { SD (median) }\end{array}$ & $\begin{array}{l}(\mathbf{R}+\mathbf{L}) / \mathbf{M} \\
\text { Mean } \pm \text { SD (median) }\end{array}$ & $\begin{array}{c}\text { L/M } \\
\text { Mean } \pm \text { SD (median) }\end{array}$ \\
\hline Sex & $1.54 \pm 1.47(1.11)$ & $1.21 \pm 0.24(1.18)$ & $0.61 \pm 0.12(0.6)$ \\
Female & $1.29 \pm 0.84(1.04)$ & $1.19 \pm 0.26(1.17)$ & $0.60 \pm 0.14(0.58)$ \\
Male & $0.022^{*}$ & 0.349 & 0.295 \\
$P$ & $1.25 \pm 0.69(1.04)$ & $1.21 \pm 0.26(1.19)$ & $0.61 \pm 0.14(0.60)$ \\
Canal Course & $1.51 \pm 1.39(1.08)$ & $1.20 \pm 0.24(1.17)$ & $0.60 \pm 0.12(0.59)$ \\
Elliptic & 0.103 & 0.482 & .337 \\
Linear & $* P<0.05$ & & \\
$P$ & & & \\
Mann Whitney U Test & & & \\
\hline
\end{tabular}

SD: standart deviation

Distances in mm; L: left mental foramen to the left mandibular ramus, R: right mental foramen to the right mandibular ramus, M: between the mental foramens, D1: mental foramen's inferior border to the mandibular basis, D2: mental foramen's superior border to the alveolar crest.

\section{DISCUSSION}

In this study, the mandibular canal course and the vertical-horizontal localization of the mental foramens were analyzed in edentulous patients for evaluation of interforaminal implant placement. The mandibular canal contains the inferior alveolar neurovascular bundle, and therefore, it is a crucial anatomical landmark in lower jaw surgery. ${ }^{6,7}$ Its morphology and position are important for preservation of the neurovascular structures within it. ${ }^{8,9}$ Aging and loss of teeth in combination results in alveolar bone atrophy which usually limits the amount of bone required for implant placement in the posterior regions of edentulous mandibulas. ${ }^{5}$ In such cases, implant-supported prosthetic rehabilitation without bone augmentation is obtained from the interforaminal area. $^{2}$ Therefore, increased horizontal distance between the mental foramens provide the anteroposterior spread of implants which becomes a clinical success parameter. ${ }^{2}$

Wical et al. mentioned in their study that alveolar bone atrophy observed superior to the mental foramen does not change the distance from the foramen to the mandibular basis, and throughout life, it remains relatively constant. ${ }^{10}$ Lindh et al. also stated that the stability of the inferior region of the mental foramen does not depend on the superior region in which alveolar bone atrophy is observed. ${ }^{11}$ Therefore, due to the stable positions of the mandibular basis and the mental foramen, the mental foramen was used as a reference point for the linear measurements in the panoramic radiographs in this study.

Craniofacial dimensions differ between individuals, especially in men being $5 \%$ to $9 \%$ larger in comparison to women. ${ }^{12}$ On this basis, rather than evaluating $\mathrm{D} 1, \mathrm{D} 2, \mathrm{~L}, \mathrm{R}, \mathrm{M}$ measurements alone, their ratios were evaluated. In all age groups, D1/D2 was higher than 1, meaning the height of the residual alveolar bone superior to the mental foramen was lower in comparison to the inferior region. This corroborated earlier studies that evaluated edentulous patients, whereas it was in contrast to dentulous patients in which the mental foramen is located closer to the mandibular basis rather than the alveolar ridge. ${ }^{12,15}$ There was a statistically significant difference in the D1/D2 value according to the age groups. The mean D1/D2 value in the 61-70 and 71-80 age groups was significantly higher than the 30-40, 41-50 and 51-60 age groups. Differences in these findings were mainly attributed to the increased alveolar bone resorption with age and period of edentulism.

The mean D1/D2 was significantly higher in the women than in the men. Sex hormones were thought to be the reason. Following menopause, reduction in estrogen levels results in increased rate of bone resorption, which cannot be compensated with bone deposition. ${ }^{15}$ As a result, alveolar process atrophy is observed more in women, making the mental foramen closer to the alveolar crest. There was no statistically significant difference in the $\mathrm{L} / \mathrm{M}$ and $(\mathrm{R}+\mathrm{L}) / \mathrm{M}$ ratios between the age groups and sexes, confirming the stability 
of this relationship throughout adult life regardless of sex.

There are several studies that have classified the mandibular course as straight, symmetrical elliptic, asymmetrical elliptic, catenary and spoon shaped. ${ }^{5,16-20}$ In this study, it was reduced to linear and elliptic to evaluate the relationship between the canal course and the vertical location of mental foramen emergence. Difference was not statistically significant in the mean D1/D2, $(\mathrm{R}+$ $\mathrm{L}) / \mathrm{M}$ and $\mathrm{L} / \mathrm{M}$ values according to the canal course. This study's results showed that canal course does not cause any significant difference in the emergence of the mental foramen either vertically or horizontally. Vertical location is clinically important in dental implant surgery for the presence of enough alveolar process height above the mental foramen, whereas the horizontal position is important for the interforaminal distance, which may be used for implant placement in the presence of posterior alveolar atrophy for an implant-supported prosthetic rehabilitation without additional bone augmentation surgeries. Although there was no difference in the mental foramens' vertical position, an elliptical course provides more space for implant placement in the posterior regions than linear ones.

The rate of linear canal course in the women was significantly higher than that in the men. This result may have been based on the increased dimensions of the cranio-facial structures in men. On the other hand, in the 71-80 and 81 and older age groups, the rate of elliptic course was significantly lower than the others. These results were in contrast with previous studies that analyzed the mandibular canal course in which an elliptic course was the most commonly observed. ${ }^{16-20}$ The reason for the difference was thought to be from evaluation of the canal course anterior to the vertical line that passes through the anterior mandibular ramus. The gradual decrease in the elliptical course of the canal as the age progresses may be analyzed with more detailed reference points to conclude on the relationship between age and mandibular canal course.

One of the limitations of the present study is that it was conducted via panoramic radiographs that allow only the mesial and distal sides of the image to be evaluated. Although panoramic radiographs represent two-dimensional view, the majority of the clinicians worldwide are still using these images for implant placement. Moreover, this study was based on the mandibular canal and mental foramen, which are the most clearly observed mandibular anatomical formations from panoramic radiography, not on implant planning. Further studies with higher accuracy can be designed with computerized tomography images.

\section{CONCLUSIONS}

In conclusion, the results of this study showed that there was no statistically significant relationship between mandibular canal course and the verticalhorizontal localization of the mental foramen. Both elliptical and linear canal courses did not affect interforaminal distances, resulting ineffective in the anteroposterior spread of implants in cases of interforaminal implant placement.

\section{ACKNOWLEDGEMENTS}

The authors would like to thank to Yeditepe University Department of Oral and Maxillofacial Radiology.

\section{AUTHORS' CONTRIBUTION}

M.C.B. participated in conceptualizing, study design, data collecting and supervision of manuscript. V.D. took part in data collecting and writing. F.C. did correction and revision of manuscript.

\section{ETHICS APPROVAL AND CONSENT TO PARCITIPATE}

This study was approved by Yeditepe University Ethical Committee (Research no. 1752-1110) and the informed consent was waived.

\section{CONFLICT OF INTEREST/SOURCE OF FUNDING}

The authors claim to have no financial interests, either directly or indirectly, in the products or information listed in this article and also declare that there are no conflicts of interest related to this study. 


\section{Implant Yerleşimi için Mandibular Kanal Seyri ve Interforaminal Bölge Arasındaki Ilişkinin Panoramik Radyografilerde Incelenmesi \\ $\ddot{O} Z$}

Amaç: Bu çalışmanın amacı dişsiz hastalarda implant uygulaması için mandibular kanal seyri ve mental foramen konumunun ilişkisinin panoramik radyografi üzerinden değerlendirilmesidir. Gereç ve Yöntemler: Bu retrospektif çalışma 788 dişsiz hastanın panoramik radyografileri ile yürütülmüşürr. Ölçümler horizontal ve vertikal olarak dijital ortamda yapılmıştır. L (sol mental foramen ile sol ramus arası mesafe), $R$ (să̆ mental foramen ile sağ ramus arası mesafe), $M$ (mental foramenler arası mesafe) horizontal ölçümler; D1 (mental foramenin alt sinırı ile basis mandibular arası mesafe) ve D2 (mental foramenin üst sinır ile alveol kret tepesi arası mesafe) ise vertikal ölçümlerdir. Mandibular kanal seyri doğrusal ve eliptik olarak iki sinıfta incelenmiştir. Demografik veriler, kanal seyri ve dijital ölçümler arası ilişki değerlendirilmiştir. Kolmogorov-Smirnov ve Shapiro Wilks testleri, Kruskal Wallis testi, ve Ki-Kare testi niteliksel verilerin karşılaş̧ırılmasında kullanılmıştır $(p<0,05)$. Bulgular: Yaş grupları arasında D1/D2 oranları ve kanal seyri açısından istatistiksel olarak anlamlı farklılık tespit edilmiştir. Kanal seyrinin eliptik görülme oranı erkeklerde (\%41,6) kadinlardan (\%26,6) anlaml derecede yüksek bulunmuştur. Kanal seyrine gore $D 1 / D 2, \quad(R+L) / M$ ve $L / M$ ortalamalar açısından istatistiksel olarak anlaml farklılık yoktur. Sonuç: Eliptik ve doğrusal kanal seyrinin interforaminal mesafeye herhangi bir etkisi yoktur, bu durum anteroposterior yönde interforaminal bölgeye implant yerleştirilmesini etkilememektedir. Anahtar Kelimeler: Mandibular kanal, kanal seyri, interforaminal bölge, kanal anatomisi, implant.

\section{REFERENCES}

1. Del Fabbro M, Bellini CM, Romeo D, Francetti L. Tilted Implants for the Rehabilitation of Edentulous Jaws: A Systematic Review. Clin Implant Dent Relat Res 2012;14:612-621.

2. Taruna M, Chittaranjan B, Sudheer N, Tella S, Abusaad M. Prosthodontic Perspective to All-On-4® Concept for Dental Implants. J Clin Diagnostic Res 2014;8:16-19.

3. Gungor K, Ozturk M, Semiz M, Brooks SL. A radiographic study of location of mental foramen in a selected Turkish population on panoramic radiograph.
Coll Antropol 2006;30:801-805.

4. Muinelo J, Suárez JA, Fernández A, Varela J, Suárez MM. Anatomical characteristics and visibility of mental foramen and accessory mental foramen: Panoramic radiography vs. cone beam CT. Med Oral Patol Oral Cir Bucal 2015;20:707-14.

5. Liu T, Xia B, Gu Z. Inferior alveolar canal course: a radiographic study. Clin Oral Implants Res 2009;20:1212-1218.

6. Farman AG, Nortje CJ. Panoramic Radiographic Appearance of the Mandibular Canal in Health and in Disease. In: Farman AG, ed. Panoramic Radiology. Springer ed. Heidelberg: Springer; 2007:107-118.

7. Worthington P. Injury to the inferior alveolar nerve during im- plant placement: a formula for protection of the patient and clinician. Int J Oral Maxillofac Implants 2004;19:731-734.

8. Kim IS, Kim SG, Kim YK, Kim JD. Position of the mental foramen in a Korean population: A clinical and radiographic study. Implant Dent 2006;15:404-411.

9. Kim ST, Hu KS, Song WC, Kang MK, Park HD, Kim HJ, et al. Location of the mandibular canal and the topography of its neurovascular structures. J Craniofac Surg 2009;20:936-939.

10. Wical KE, Swoope CC. Studies of residual ridge resorption. Part I. Use of panoramic radiographs for evaluation and classification of mandibular resorption. $\mathrm{J}$ Prosthet Dent 1974;32:7-12.

11. Lindh C, Petersson A, Klinge B. Measurements of distances related to the mandibular canal in radiographs. Clin Oral Implants Res 1995;6:96-103.

12. Foley TF, Mamandras AH. Facial growth in females 14 to 20 years of age. Am J Orthod Dentofacial Orthop 1992;101:248-254.

13. Cartes G, Garay I, Deana NF, Navarro P, Alves N. Mandibular Canal Course and the Position of the Mental Foramen by Panoramic X-Ray in Chilean Individuals. Biomed Res Int 2018;2018:1-10.

14. Manja CD, Abolmaesoomi M. Panoramic radiography assessment about difference of morphometric and position of mandibular canal in relation to gender at the age of 17-20 years. Int J Appl Dent Sci 2017;3:144-147.

15. Almeida M, Laurent MR, Dubois V, Claessens F, O'Brien CA, Bouillon R, et al. Estrogens and Androgens in Skeletal Physiology and Pathophysiology. Physiol 
Rev 2017;97:135-187.

16. Jung YH, Cho BH. Radiographic evaluation of the course and visibility of the mandibular canal. Imaging Sci Dent 2014;44:273-278.

17. Mirbeigi S, Kazemipoor M, Khojastepour L. Evaluation of the course of the inferior alveolar canal: The first CBCT study in an Iranian population. Polish $\mathbf{J}$ Radiol 2016;81:338-341.

18. Alok A, Singh S, Kishore M, Bhattacharya P. A Radiographic Study to Evaluate the Course and
Visibility of the Mandibular Canal in Darbhanga Population: An Original Research. Int J Contemp Med Res 2019;6:15-18.

19. Ozturk A, Potluiri A, Vieira AR. Position and course of mandibular canal in skulls. Oral Surg Oral Med Oral Pathol Oral Radiol 2012;113:453-458.

20. Gowgiel JM. The position and course of the mandibular canal. J Oral Implantol 1992;18:383-385. 